\title{
In vitro Antibacterial Effects of Salvia sclarea, Eucalyptus Globulus and Eugenia Caryophyllata Essential oils Against Multidrug Resistant Corynebacterium spp Clinical Isolates
}

\section{Sana Alibi ${ }^{1,2,3 *}$, Asma Ferjani ${ }^{1}$, Hedi Ben Mansour ${ }^{2}$, Jesús Navas ${ }^{3}$}

${ }^{1}$ Laboratory of microbiology-immunology, Research unit UR12SP34, CHU F. Hached, Sousse, Tunisia.

${ }^{2}$ Research Unit Analysis and Process Applied to the Environment (UR17ES32)- Higher Institute of Applied Sciences and Technology, Mahdia,Tunisia ${ }^{3}$ BIOMEDAGE Group, Faculty of Medicine, University of Cantabria, Santander, Spain

*Corresponding author: Sana Alibi, Laboratory of microbiology-immunology, Research unit UR12SP34, CHU F. Hached, Sousse, Tunisia. Received date: January 23, 2020; Accepted date: January 29, 2020; published date: February 03, 2020

Citation: Sana A, Asma F, Hedi BM, Jesús N (2020) In vitro Antibacterial Effects of Salvia sclarea, Eucalyptus Globulus and Eugenia Caryophyllata Essential oils Against Multidrug Resistant Corynebacterium spp Clinical Isolates. J Clinical Research and Reports, 2(3);

DOI: $10.31579 / 2690-1919 / 020$

Copyright: (C) 2020 Sana Alibi. This is an open access article distributed under the Creative Commons Attribution License, which permits unrestricted use, distribution, and reproduction in any medium, provided the original work is properly cited.

\begin{abstract}
Objectives: Multidrug resistant Corynebacterium species are increasingly reported as the ethiological agent of various clinical infections. Thus, the purpose of this research was to evaluate the in vitro antimicrobial activity of three essential oils Salvia sclarea, Eucalyptus globulus and Eugenia caryophyllata against Corynebacterium species.

Methods: Twenty-four multidrug resistant strains including C. striatum, C. amycolatum, C. urealyticum, C. aurimucosum, C. imitans, and $C$. jeikeium were used in the study. Inhibition diameter zone, minimum inhibitory concentration and minimum bactericide concentration of these oils were determined using agar disc diffusion method and microdilution method. Tigecycline was used as positive control.

Results: Our study showed that Eugenia caryophyllata had the best activity. Eucalyptus globulus extract exhibited a moderate activity and Salvia sclarea was inactive against all the species tested. We found that $C$. amycolatum was more resistant to the essential oils than other species. On the other hand, tigecycline was effective on the majority of the strains (37.5\%), but his action was lower than Eugenia caryophyllata oil.

Conclusion: These results support the use of clove oil as a natural alternative to treat infections caused by multidrug resistant corynebacteria.
\end{abstract}

Key Words: Essential oil; Corynebacterium; antibacterial effect; tigecycline

\section{Introduction}

Essential oils from aromatic and medicinal plants have been known since antiquity to possess biological activity, notably antibacterial properties $[1,2]$. Nowadays, the use natural, effective and nontoxic antimicrobial agents have been developed interestingly in particular with the emergence of many drug resistances among a wild range of bacteria. In fact, the prolonged exposure to antibiotics in clinic significantly increases the manifestation of opportunistic pathogens notably Corynebacterium spp. The spread of antimicrobial resistance Corynebacterium species is a known problem worldwide [3-5]. Thus, there is growing interest in using natural antimicrobial compounds to treat patients suffering from infections due to multidrug resistance Corynebacterium species. Previous studies reported the antimicrobial activity of essential oils from clove (Eugenia caryophyllata), eucalyptus (Eucalyptus globulus), and sage (Salvia sclarea) against bacteria [6-9]. Thereby, in this study we evaluated the antimicrobial potency of Eos extracted from these plants against MDR Corynebacterium strains responsible for clinical infections and we compared their activity to tigecycline.

\section{Materials and Methods}

\subsection{Essential oils obtention}

Three medicinal plants selected for this study were Salvia sclarea, Eucalyptus globulus and Eugenia caryophyllata. Brut EOs were purchased from Gandiva Cosmética Vegetal (Spain) and stored at room temperature until tested.

\subsection{Bacterial strains}

A total of 24 MDR Corynebacterium spp strains including $C$. striatum $(\mathrm{n}=15), C$. amycolatum $(\mathrm{n}=5), C$. urealyticum $(\mathrm{n}=2), C$. aurimucosum $(\mathrm{n}=1), C$. imitans $(\mathrm{n}=1)$, and $C$. jeikeium $(\mathrm{n}=1)$ were collected from patients hospitalized at the University Hospital of F. Hached, Sousse Tunisia. Clinical strains were recovered from different specimens (Table I) as follows: surgical wound exudates $(n=10)$, vaginal swabs $(n=1)$, ear effusions $(n=3)$, urine $(n=3)$, sputum $(n=2)$, tracheal aspirates $(n=2)$, eye effusions $(n=2)$, central venous catheter tips $(n=2)$.

Isolated bacterial strains were firstly identified by conventional biochemical methods and Api Coryne V.2 (BioMerieux®, Marcyl'Etoile, France). Then, MALDI-TOF-MS (Vitek MS, BioMérieux®) was used for final identification.

Susceptibility to tigecycline $(15 \mu \mathrm{g})$ used as control was determined using disc diffusion method on Muller-Hinton blood agar (biorad, France) 


\begin{tabular}{|c|c|c|}
\hline $\begin{array}{l}\text { Strains } \\
\text { number }\end{array}$ & Species & Specimens \\
\hline 1 & C. striatum & Sputum \\
\hline 2 & C. striatum & Surgical wound exudates \\
\hline 3 & C. striatum & urine \\
\hline 4 & C. striatum & Tracheal aspirates \\
\hline 5 & C. striatum & Ocular wound exudates \\
\hline 6 & C. striatum & Surgical wound exudates \\
\hline 7 & C. striatum & Surgical wound exudates \\
\hline 8 & C. striatum & Surgical wound exudates \\
\hline 9 & C. striatum & Tracheal aspirates \\
\hline 10 & C. striatum & Tracheal aspirates \\
\hline 11 & C. striatum & Central venous catheter tips \\
\hline 12 & C. striatum & Surgical wound exudates \\
\hline 13 & C. striatum & Ear wound exudates \\
\hline 14 & C. striatum & Ear wound exudates \\
\hline 15 & C. striatum & Ear wound exudates \\
\hline 16 & C. amycolatum & Surgical wound exudates \\
\hline 17 & C. amycolatum & Surgical wound exudates \\
\hline 18 & C. amycolatum & Vaginal swab \\
\hline 19 & C. amycolatum & Central venous catheter tips \\
\hline 20 & C. urealyticum & Urine \\
\hline 21 & C. urealyticum & Urine \\
\hline 22 & C. aurimucosum & Surgical wound exudates \\
\hline 23 & C. imitans & Surgical wound exudates \\
\hline 24 & C. jeikeium & Surgical wound exudates \\
\hline
\end{tabular}

according to Clinical and Laboratory Standards Institute recommendations [10]. The minimum inhibitory concentrations (MICs) for 12 drugs including: Kanamycin, erythromycin, clindamycin, doxycycline, ciprofloxacin, moxifloxacin, penicillin, cefotaxime, rifampicin, vancomycin, linezolid and daptomycin were determined by using micro-dilution in cation adjusted Muller-Hinton broth in accordance with guidelines of the CLSI [10]. All the strains tested were resistant to kanamycin, erythromycin, clindamycin, ciprofloxacin, moxifloxacin, cefotaxime, penicillin, and rifampicin.

\subsection{Essential oils antibacterial activity}

\subsubsection{Determination of diameter of inhibition zone}

The susceptibility of MDR pathogens to the 3 essential oils was tested by disc diffusion method Muller Hinton Agar. Sterile blank discs of $6 \mathrm{~mm}$ diameter (Biomérieux, Marcy-l'Etoile, France) loaded with $20 \mu \mathrm{l}$ of each oil were placed on solidified medium, previously inoculated on the surface agar with $200 \mu \mathrm{L}$ of $10^{6} \mathrm{cfu} / \mathrm{mL}$ suspension. The plates were incubated at $37^{\circ} \mathrm{C}$ for 24 hours. Diameter of zone of inhibition of growth was measured.

\subsubsection{Determination of the MIC and MBC}

The minimum inhibitory concentration (MIC) and the minimum bactericidal concentration (MBC) for The essential oils, were determined using broth dilution method. Serial dilutions (10 dilutions) of essential oils $(50 \mu \mathrm{l} / \mathrm{ml})$ were prepared with BHI broth medium. One colony of each bacterial strain was sampled with a loop, then inoculated in $25 \mathrm{~mL}$ BHI broth and incubated for $18-24 \mathrm{~h}$ at $37^{\circ} \mathrm{C}$. The suspension was diluted to obtain $10^{6} \mathrm{cfu} / \mathrm{mL}$ and $50 \mu \mathrm{l}$ of the solution were placed in each well. Final solutions were incubated at $37^{\circ} \mathrm{C}$ overnight. The MIC was considered as the lowest concentration that prevented the visible growth. The MBC was determined by subculturing $100 \mu \mathrm{L}$ from each test well $\geq$ MICs onto plate count agar plates. MBC was defined as the lowest concentration resulting in a negative subculture or giving presence of only one colony after incubation. Bacteriostatic activity has been defined as a ratio of $\mathrm{MBC}$ to MIC >4 [11].

\section{Results and Discussion}

The antimicrobial activities of $S$. sclarea, E. globulus and E. caryophyllata against 24 MDR clinically relevant Corynebacterium spp strains was evaluated.

Bacterial susceptibility to the essential oils, as determined by the agar diffusion method, showed that the selected essential oils have variable antibacterial activity.

E. caryophylatta EO showed remarkable activity against the all the tested strains (Table I). Our study was in concordance with other findings reporting the potent antibacterial effect of this EO [12]. It was active against food-borne bacteria $[13,14]$ and $H$. pylori $[15,16]$.

This activity is due to the eugenol, the major compount of $E$. caryophylatta EO [17] .

Our results revealed that E. globulus EO had a moderate activity against the strains tested. The inhibition diameters zones were lower than those obtained with the clove oil, ranging from $7 \mathrm{~mm}$ to $20 \mathrm{~mm}$ (Table II).

\begin{tabular}{lllll}
\hline \multicolumn{5}{c}{ Inhibition zone diameter $(\mathrm{mm})$} \\
\hline Strains & $\begin{array}{l}\text { Eugenia } \\
\text { caryophyllata }\end{array}$ & $\begin{array}{l}\text { Eucalyptus } \\
\text { globulus }\end{array}$ & $\begin{array}{l}\text { Salvia } \\
\text { sclarea }\end{array}$ & Tigecyclin \\
\hline 1 & 30 & 18 & 15 & 20 \\
2 & 25 & 10 & 9 & 20 \\
3 & 25 & 16 & 10 & 20 \\
4 & 23 & 20 & 10 & 20 \\
5 & 25 & 12 & 10 & 30 \\
6 & 20 & 15 & 15 & 22 \\
7 & 22 & 15 & 10 & 22 \\
8 & 25 & 18 & 10 & 24 \\
9 & 20 & 15 & 8 & 22 \\
10 & 20 & 7 & 9 & 20 \\
11 & 20 & 18 & 10 & 24 \\
12 & 18 & 13 & 10 & 18 \\
13 & 22 & 8 & 8 & 20 \\
14 & 22 & 10 & 10 & 20 \\
15 & 20 & 13 & 8 & 18 \\
16 & 8 & 8 & 8 & 24 \\
17 & 28 & 17 & 15 & 26 \\
\hline
\end{tabular}




\begin{tabular}{lllll}
\hline 18 & 28 & 18 & 15 & 30 \\
19 & 22 & 10 & 8 & 26 \\
20 & 24 & 7 & 10 & 28 \\
21 & 20 & 15 & 10 & 24 \\
22 & 22 & 10 & 10 & 20 \\
23 & 10 & 12 & 10 & 18 \\
24 & 10 & 13 & 10 & 20 \\
\hline
\end{tabular}

For the majority of the strains (52\%), the diameters were comprised between 10 and $18 \mathrm{~mm}$. The lowest values were exhibited by $C$. amycolatum strains. The MICs values ranges proportionally to the inhibition diameter. They ranged from $0.05 \mu 1$ to $50 \mu 1$. MBCs results showed either bacteriostatic or bactericide effect of this EO (Table III).

Table II. Inhibition diameter zone ( $\mathrm{mm}$ ) of different plant essential oil on

Corynebacterium spp strains

\begin{tabular}{|c|c|c|c|c|c|c|}
\hline Oils & \multicolumn{2}{|c|}{ Eugenia caryophyllata } & \multicolumn{2}{|c|}{ Eucalyptus globulus } & \multicolumn{2}{|c|}{ Salvia sclarea } \\
\hline Strains & $\mathrm{MIC}(\mu \mathrm{l} / \mathrm{ml})$ & $\mathrm{MBC}(\mu \mathrm{l} / \mathrm{ml})$ & $\mathrm{MIC}(\mu \mathrm{l} / \mathrm{ml})$ & $\mathrm{MBC}(\mu \mathrm{l} / \mathrm{ml})$ & $\mathrm{MIC}(\mu \mathrm{l} / \mathrm{ml})$ & $\operatorname{MBC}(\mu \mathrm{l} / \mathrm{ml})$ \\
\hline 1 & 0.05 & 1.6 & 0.2 & 6.25 & 6.25 & NA \\
\hline 2 & 0.4 & 12.5 & 25 & 25 & 50 & NA \\
\hline 3 & 0.4 & 12.5 & 12.5 & 50 & 50 & NA \\
\hline 4 & $<0.05$ & 1.6 & 0.05 & 12.5 & 50 & NA \\
\hline 5 & $<0.05$ & 1.6 & 25 & 50 & 25 & NA \\
\hline 6 & $<0.05$ & 1.6 & 0.2 & 50 & 6.25 & NA \\
\hline 7 & $<0.05$ & 3.125 & 25 & 50 & 50 & NA \\
\hline 8 & $<0.05$ & 3.125 & 3.125 & 25 & 25 & NA \\
\hline 9 & $<0.05$ & 1.6 & 25 & 50 & 50 & NA \\
\hline 10 & 0.2 & 12.5 & 25 & 25 & 6.25 & NA \\
\hline 11 & 0.2 & 12.5 & 0.8 & 25 & 50 & NA \\
\hline 12 & 0.2 & 12.5 & 25 & 50 & 50 & NA \\
\hline 13 & $<0.05$ & 1.6 & 0.2 & 50 & 50 & NA \\
\hline 14 & $<0.05$ & 1.6 & 50 & 50 & 6.25 & NA \\
\hline 15 & $<0.05$ & 1.6 & 6.25 & 50 & 50 & NA \\
\hline 16 & 0.125 & 3.125 & 50 & 50 & 50 & NA \\
\hline 17 & $<0.05$ & 1.6 & 50 & 50 & 50 & NA \\
\hline 18 & $<0.05$ & 1.6 & 50 & 50 & 50 & NA \\
\hline 19 & 0.125 & 6.25 & 50 & 50 & 50 & NA \\
\hline 20 & $<0.05$ & 3.125 & 50 & 50 & 50 & NA \\
\hline 21 & 0.4 & 12.5 & 50 & 50 & 50 & NA \\
\hline 22 & $<0.05$ & 1.6 & 50 & 50 & 25 & NA \\
\hline 23 & $<0.05$ & 1.6 & 25 & 50 & 50 & NA \\
\hline 24 & $<0.05$ & 1.6 & 25 & 50 & 50 & NA \\
\hline
\end{tabular}

Table III: MIC and MBC obtained for the 3 essential oils tested against orynebacterium spp strains.

Similarly, eucalyptus oil was used in various studies where its activity was found either moderate $[8,18,19]$ or low [20]. Singh et al [8] found that Eucalyptus oil inhibited growth in $S$. indicum and E. coli but the area of inhibition zone was much less in comparison to clove oil, while Staphylococcus and Bacillus strains were found completely insensitive to eucalyptus oil. However, other studies reported that the extract of $E$. globulus potently inhibited the growth of E. coli, S. aureus [21] and fish pathogenic bacteria [22].

The antibacterial activity of Eucalyptus extracts has been due to his principal constituents oxygenated monoterpenes and terpinen-4-ol and other components such as $\alpha$-pinene, $\beta$-pinene, $\alpha$-phellandrene, 1,8 cineole, limonene, terpine-4-ol, aromadendrene, epiglobulol, piperitone and globulol [23].

It seemed that the presence of 1,8-cineole and $\alpha$-phellandrene coupled with low antioxidant activity and high cytotoxic effect makes eucalyptus oil less effective against the control of bacterial growth. Thus, eucalyptus oil is not much suited for medicinal purposes, but can be used as repellant or anti-feedant in insecticidal formulation [8].

In this study, sage oil has shown the lowest effect against our strains. All the isolates tested exhibited diameter $\leq 15 \mathrm{~mm}$. Only undiluted oil was active against the strains. The MICs value obtained were high for almost all the strains. Sepahvand et al [24] has demonstrated that $S$. sclarea essential oil did have different anti-bacterial effects among the microorganisms tested. In accordance to our study, it has a low effect on $P$. aeruginosa. Unlikely, Cui et al [9] proved that this oil was highly lethal to E. coli, S. aureus, B. pumilus, B. subtilis, $K$. pneumoniae, $S$. typhimurium and $P$. aeruginosa. S. sclarea oil was an effective bacterial inhibitor and bactericide with a broad antibacterial spectrum. It damaged the cell membrane and changed its permeability, leading to the release of some cytoplasm such as macromolecular substances, ATP and DNA. The antimicrobial action of $S$. sclarea essential oil is not only attributable to a unique pathway, but also involves a series of events both on the cell surface and within the cytoplasm. Two diterpenoids, salvipisone and aethiopinone contained in Salvia sclarea are known for their high antibacterial activity [24].

In our study, we noted that $C$. amycolatum was the most insensitive specie among the strains tested. This may be explained by the particular structure of his cell wall which lacked mycolic acid but contains a cation-selective cell wall channel that may be responsible for the limited permeability of the cell wall to EO and notably to different antibiotics. The structure of the cellular walls justifies also the differences observed between Grampositive and Gram-negative bacteria [9].

We observed that the susceptibility an EO varied among different species included in the study and among strains belonging to the same species. These discrepancies may be explained by the same mechanisms of antibiotic resistance including adaptation of a strain to ecological environment, selection pression and cross breeding [25].

Among the 24 strains tested, 9 (37.5\%) strains showed resistance to tigecycline. Salas et al. [26] and Fernandez-Roblas et al. [27] reported good activity of this antibiotic against coryneform bacteria. Tigecyclin 
was more potent than E. globulus and S. sclarea. However, the diameters of inhibition zone of $E$. caryophyllata were higher than the tigecycline for the majority of the strains. This fact proved the potential activity of clove oil against Corynebacterium spp.

\section{Conclusion}

In this study, results obtained showed that clove EO had the highest activity against MDR Corynebacterium species. His activity was slightly higher than tigecycline. However, the sage oil was inactive on all the species tested. E. caryophyllata EO seems to be an important alternative treatment in nosocomial Corynebacterium infections ranging from cutaneous infections to urinary tract infections.

Conflict of interest: None.

\section{References}

1. Hassan ST, Majerová M, Šudomová M, Berchová K (2015) Antibacterial activity of natural compounds - essential oils. Ceska. Slov. Farm, 64(6):243-253.

2. de Billerbeck VG (2007) Huiles essentielles et bactéries résistantes aux antibiotiques Phytothérapie., 5(5): 249-253.

3. Campanile F, Carretto E, Barbarini D, Grigis A, Falcone M (2009) Clonal multidrug-resistant Corynebacterium striatum strains, Italy. Emerg. Infect. Dis., 15(1):75-78.

4. Baio PVP, Mota HF, Freitas AD, Gomes DLR et al (2013) Clonal multidrug-resistant Corynebacterium striatum within a nosocomial environment, Rio de Janeiro, Braz. Memó. Inst. Oswal. Cruz., 108(1):23-29.

5. Otsuka Y, Ohkusu K, Kawamura Y, Baba S, Ezaki T (2006) Emergence of multidrug-resistant Corynebacterium striatum as a nosocomial pathogen in long-term hospitalized patients with underlying diseases. Diagn. Microbiol. Infect. Dis., 54(2):109-114.

6. Yadav MK, Park SW, Chae SW, Song JJ, Kim HC (2013) Antimicrobial activities of Eugenia caryophyllata extract and its major chemical constituent eugenol against Streptococcus pneumoniae. A.P.M.I.S., 121(12):1198-1206.

7. Sabahat S, Perween T (2007) Antimicrobial activities of Emblica officinalis and Coriandrum sativum against Gram positive bacteria and Candida albicans. Pak.J. Bot., 39(3): 913-917.

8. Singh A, Sharma S, Singh S, Bond J, Rustagi A (2014) Evaluation of antibacterial properties of essential oils from clove and eucalyptus. Asian. J. Pharm. Clin. Res., 7(5):291-294.

9. Cui H, Zhang X, Zhou H, Zhao C, Lin L (2015) Antimicrobial activity and mechanisms of Salvia sclarea essential oil. Bot. Stud., $56: 16$.

10. Method for Antimicrobial Dilution and Disk Susceptibility Testing of Infrequently Isolated or Fastidious Bacteria. Approved Standard M45-A. Wayne, Clinical and Laboratory Standards Institute (CLSI), 2014.

11. Pankey GA, Sabath LD (2004) Clinical Relevance of Bacteriostatic versus Bactericidal Mechanisms of Action in the Treatment of Gram-Positive Bacterial Infections. Clin. Infect. Dis.,38(6):864-870.

12. Trajano NV, Lima OE, de Souza LE, Travassos RA (2010) Inhibitory effect of the essential oil from Eugenia caryophyllata
Thumb leaves on coalho cheese contaminating microorganisms. Cienc. Tecnol. Aliment. Campinas., 30(4): 1001-1006

13. Smith-Palmer A, Stewart J, Fyfe L (1998) Antimicrobial properties of plant essential oils and essences against five important food-borne pathogens. Lett. Appl. Microbiol., 26(2):118-122.

14. López P, Sánchez C, Batlle R, Nerín C (2005) Solid- and vaporphase antimicrobial activities of six essential oils: susceptibility of selected foodborne bacterial and fungal strains. J. Agric. Food. Chem. 24;53(17):6939-6946.

15. Bae EA, Han MJ, Kim NJ, Kim DH (1998) Anti-Helicobacter pylori activity of herbal medicines. Biol. Pharm. Bull., 21(9):990-992.

16. Li Y, Xu C, Zhang Q, Liu JY, Tan RX (2005) In vitro antiHelicobacter pylori action of 30 Chinese herbal medicines used to treat ulcer diseases. J. Ethnopharmacol., 98(6): 329-333.

17. Suresh P, Ingle VK, Vijaya LV (1992) Antibacterial activity of Eugenol in comparison with other antibiotics. J. Fd. Sci. Technol., 29: 254-256.

18. Cimanga K, Kambu K, Tona L, Apers S, De Bruyne T et al (2002) Correlation between chemical composition and antibacterial activity of essential oils of some aromatic medicinal plants growing in the Democratic Republic of Congo. J. Ethnopharmacol.,79(2):213-220.

19. Takarada K, Kimizuka R, Takahashi N, Honma K, Okuda K (2004) A comparison of the antibacterial efficacies of essential oils against oral pathogens. Oral. Microbiol. Immunol., 19(1):61-64.

20. Prabuseenivasan S, Jayakumar M, Ignacimuthu S (2006) In vitro antibacterial activity of some plant essential oils. BMC. Complement. Altern. Med., 30:6-39.

21. Bachir RG, Benali M (2012) Antibacterial activity of the essential oils from the leaves of Eucalyptus globulus against Escherichia coli and Staphylococcus aureus. Asian. Pac. J. Trop. Biomed., 2(9):73942.

22. Park JW, Wendt M, Heo GJ (2016) Antimicrobial activity of essential oil of Eucalyptus globulus against fish pathogenic bacteria. Lab. Anim. Res., 32(2):87-90.

23. Nezhad FM, Zeigham H, Mota A, Sattari M, Yadegar A (2009) Antibacterial Activity of Eucalyptus Extracts on Methicillin Resistance Staphylococcus aureus. Research. J. Biol. Sci., 4: 905908.

24. Sepahvand R, Delfan B, Ghanbarzadeh S, Rashidipour M et al (2014) Chemical composition, antioxidant activity and antibacterial effect of essential oil of the aerial parts of Salvia sclareoides. Asian. Pacific. J. Trop. Med.,7(1): S491-S496.

25. Walencka E, Rozalska S, Wysokinska H, Rozalski M, Kuzma L (2007) Salvipisone and aethiopinone from Salvia sclarea hairy roots modulate staphylococcal antibiotic resistance and express antibiofilm activity. Planta. Med.,73(6):545-51.

26. Salas C, Calvo J, Martínez-Martínez L (2008) Activity of Tigecycline against Coryneform Bacteria of Clinical Interest and Listeria monocytogenes. Antimicrob. Agents. Chemother. 52(4):1503-1505.

27. Fernandez-Roblas R, Adames H, Martín-de-Hijas NZ, Almeida DG et al (2009) In vitro activity of tigecycline and 10 other antimicrobials against clinical isolates of the genus Corynebacterium. Int. J. Antimicrob. Agents., 33(5):453-455. 
This work is licensed under Creative Commons Attribution 4.0 License

To Submit Your Article Click Here: Submit Manuscript

DOI: $10.31579 / 2690-1919 / 020$
Ready to submit your research? Choose Auctores and benefit from:

* fast, convenient online submission

* rigorous peer review by experienced research in your field

* rapid publication on acceptance

* authors retain copyrights

* unique DOI for all articles

* immediate, unrestricted online access

At Auctores, research is always in progress.

Learn more www.auctoresonline.org/journals/journal-of-clinical-researchand-reports 